Journal of the Scholarship of Teaching and Learning, Vol. 20, No. 3, December 2020, pp. 64-80.

doi: 10.14434/josotl.v20i3.28718

\title{
Exploring Socialization and Teaching Self-Efficacy through a Community of Practice for International Teaching Assistants
}

\author{
Leah Hakkola \\ University of Maine \\ Leah.hakkola@maine.edu \\ Ming Tso Chien \\ University of Maine \\ Ming.chien@maine.edu \\ Karen Pelletreau \\ University of Maine \\ Karen.pelletreau@maine.edu
}

\begin{abstract}
International teaching assistants face unique and often challenging experiences when entering graduate studies in the United States. Challenges include navigating socialization into graduate education, and instructional, linguistic, and social difficulties. Communities of Practice can impart academic knowledge and information to assist with teacher self-efficacy, while simultaneously belping with creating a sense of community for graduate students. This multi-methods case study examined the impacts of a Community of Practice designed to socialize international teaching assistants and improve teacher self-efficacy. Researchers found that participation in this learning community enhanced teaching self-efficacy, heightened self-confidence, strengthened social relationships, and increased participants' sense of belonging.
\end{abstract}

Keywords: international teaching assistants, community of practice, socialization, teacher self-efficacy.

\section{Introduction}

In 2017, international graduate students made up nearly $20 \%$ of the total national enrollment in the United States (Okahana \& Zhou, 2019). Just like their domestic counterparts, many international graduate students in the U.S. take on the task of teaching undergraduate or graduate courses, sometimes in order to obtain funding from an assistantship, other times in order to become prepared for future academic positions (Okahana \& Zhou, 2019). The international graduate students who engage with teaching are often referred to as international teaching assistants (ITAs). ITAs at research institutions contribute significantly to undergraduate education, often serving as instructors of record for introductory courses, or as teaching assistants for large enrollment courses, where they serve as the primary point of contact for the course (Jia \& Aldous Bergerson, 2008).

According to UNESCO (2019), international students in the United States can be defined as individuals "who have crossed a national or territorial border for the purpose of education and are now enrolled outside their country of origin." In 2018, national data for enrollment showed $77 \%$ of admitted international students were from Asian countries (Okahana \& Zhou, 2019). A large percentage of these students play a significant role in college classrooms as ITAs (Jia \& Aldous Bergerson, 2008). Many of them have little to no prior teaching experience in English in higher education, especially in the United States (Chalupa \& Lair, 2000). Furthermore, the educational culture in their country of origin is often quite different from that in the United States (Chalupa \& Lair, 2000). Because of these linguistic, cultural and educational differences, ITAs face unique and often 
challenging experiences when entering graduate studies in the United States (Ashavskaya, 2018). These challenges include navigating socialization into graduate education (Jia \& Aldous Bergerson, 2008; Strayhorn, 2012), classroom management (Ashavskaya, 2015), and linguistic, social, and cultural issues (Ashavskaya, 2018).

To help ITAs deal with these challenges, some higher education institutions have designed targeted training programs for this population beyond language proficiency (Chalupa \& Lair, 2000; Jia \& Aldous Bergerson, 2008; Meadows, Olsen, Dimitrov, \& Dawson, 2015; Swan, Kramer, Gopan, Shi, \& Roth, 2017). For example, Meadows et al. (2015) compared a specialized program designed to promote intercultural teaching competence for ITAs with a general, intensive workshop designed for all new teaching assistants (TAs) regardless of their country of origin. They found that the specialized program was more effective in improving not only the ITAs' teaching self-efficacy but also various aspects of their teaching. In a similar targeted approach, Ashavskaya (2018) found that providing ongoing mentoring sessions and reflection had positive impacts on teaching practices for ITAs. A third study discovered that an ITA training program focused on ITA socialization and self-efficacy improved presentation and teaching skills, smoothed the transition into the university, and enhanced cross-cultural learning (Jia \& Aldous Bergerson, 2008).

The use of community building models has proven effective in helping with academic success and in promoting socialization in higher education settings. Two prominent models include Faculty Learning Communities (Cox \& McDonald, 2017) and Communities of Practice (Wenger 1998). Despite their distinct characteristics, they are both social models that rely heavily on participant interaction. Several studies have demonstrated the effectiveness of these models in promoting change in faculty practices, including those targeting teaching assistants (Jia \& Aldous Bergerson, 2008; Thompson, Marbach-Ad, Egan \& Smith, 2015). However, little is known about how Communities of Practice (CoPs) may affect the experience of international teaching assistants specifically. Accordingly, this study aimed to investigate how a CoP designed distinctly for ITAs could improve ITAs' socialization into the community as evidenced by enhanced teaching self-efficacy and sense of belonging.

\section{Review of Literature}

Research has shown that lack of community for graduate students can have direct negative impacts on their experiences, and may even lead to them leaving graduate programs (Lovitts, 2001; Singh, 2018). For international students, research has demonstrated the positive relationship between a sense of belonging and overall academic success (e.g., Glass \& Westmont, 2014; Singh, 2018; Strayhorn, 2012). It appears that providing opportunities for socialization and community building may play an equally important role in preparing future faculty as providing requisite information such as how to teach and how to write a research proposal (Chalupa \& Lair, 2000; Gorush, 2017).

According to a study focusing on graduate student experiences, Strayhorn (2012) found that positive socialization is a key component to graduate students' sense of belonging and academic success. Socialization in this context includes "activities such as orientation programs, faculty-student advising, social gatherings among peers and staff, research training, and internships, to name a few" (Strayhorn, 2012, p. 100). In these experiences, graduate students obtain important information about how to successfully navigate their particular fields of study given the distinct contexts of their program areas. Without this critical knowledge, data suggest that graduate students may fail to develop meaningful relationships with students, peers, and faculty, which subsequently could lead to feelings of isolation and withdrawal from graduate school (Strayhorn, 2012). While research demonstrates the need for positive socialization for all graduate students (Bair \& Haworth, 2005), some have argued

Journal of the Scholarship of Teaching and Learning, Vol. 20, No. 3, December 2020. josotl.indiana.edu 
that this process is even more important for international students, given their need to adapt to new cultural environments (Chalupa \& Lair, 2000; Chavajay, 2013; Singh, 2018).

\section{Sense of Belonging}

Scholars have argued that sense of belonging is critical to effective socialization, development, and success in higher education (Museus et al., 2017; Mwangi, 2016; Strayhorn, 2012). Accordingly, this concept has been explored from several vantage points and disciplinary perspectives (e.g., Glass, 2018; Museus et al., 2017; Singh, 2018; Yi \& Saelua, 2018). Strayhorn (2012) has defined sense of belonging as follows:

Students' perceived social support on campus, a feeling or sensation of connectedness, the experience of mattering or feeling cared about, accepted, respected, valued by, and important to the group (e.g., campus community) or others on campus (e.g., faculty, peers). (p. 17)

Some recent studies have explored international students' sense of belonging by examining how ITAs' identity as international students intersects with other social identities such as gender (e.g., Le, LaCost, \& Wismer, 2016) and race (e.g., Mwangi, 2016). Because ITAs embody these intersections and experiences as both international students and graduate teaching assistants, positive socialization and sense of belonging are likely key components to successful academic, personal, and professional engagement in the university.

Other studies have looked at the impact of relationships on international students' sense of belonging. For example, Curtis, Steward, and Ostrove (2013) found that advisor support was associated with a stronger sense of belonging and academic self-concept for both international students and their domestic counterparts. Another study examined international students' narratives about faculty and found their narratives marked with joy, trust, anticipation, and surprise (Glass, Kociolek, Wongtrirat, Lynch, \& Cong, 2015). The researchers also found variations in these narratives from different subgroups among the international students they studied, depending on their levels of financial resources and academic preparedness (Glass et al., 2015). Alternatively, Yao (2016b) examined the interpersonal relationships between international students and American students and found that for international students, making meaningful connections with their American peers turned out to be more challenging than they had anticipated.

A significant portion of scholarship on international students has focused on cultural and language barriers (e.g., Yao, 2016a; Yeh \& Innose, 2003), interpersonal problems (e.g., Glass, 2018; Khawaja \& Stallman, 2011), and homesickness (e.g., Jung, Hetch, \& Wadsworth, 2007; Sun, Hagedorn, \& Zhang, 2016). Consistently, research has established that international students experience a range of additional and unique stressors in their transition to U.S. institutions that may influence their sense of belonging (Chalupa \& Lair, 2000; Shadowen, Williamson, Guerra, Ammigan, \& Drexler, 2019). In particular, Shadowen and colleagues found that factors of English fluency, perceived discrimination, and transitioning to a new culture were all positively correlated with symptoms of depression in international students, that could have led to isolation from their peers.

A second major line of research on international students has been related to academic success (Curtis et al., 2013), retention (Ashavskaya, 2018), and adjustment (Singh, 2018). Less research has centered on what factors may positively affect socialization and teaching self-efficacy specifically for ITAs (Jia \& Aldous Bergerson, 2008). Moreover, while existing literature highlights the importance of sense of belonging in both the social and academic development of students (Strayhorn, 2012), it

Journal of the Scholarship of Teaching and Learning, Vol. 20, No. 3, December 2020. josotl.indiana.edu 
remains unclear as to how ITAs may experience this concept in a community of practice focused on teaching self-efficacy.

\section{Teaching Self-Efficacy}

Teaching self-efficacy, according to DeChenne, Enochs, and Needham (2012), is “an instructor's belief in his or her ability to teach students in a specific context" (p. 102). This concept is associated with teaching behaviors and student achievement, and in the context of this study, it can be used as a measure of ITAs' development as instructors. Scholars acknowledge that ITAs have played a critical role in providing instruction and support to American students (Jia \& Aldous Bergerson, 2008; Singh, 2018), which indicates that their teaching self-efficacy is an important area to understand.

Much of the extant research on teaching self-efficacy has focused on the role of professional development (Jia \& Aldous Bergerson, 2008), how ITAs influence American students' educational outcomes (O’Neal, Wright, Cook, Perorazio, \& Purkiss, 2007), and the quality of instruction provided by ITAs (Kim, 2009). For instance, Dechenne et al. (2012) focused on graduate teaching assistants in the science, technology, engineering, and mathematics programs and found that teaching self-efficacy was correlated to various measures of professional development as well as teaching experience. Relatedly, Kim (2009) examined perceived English proficiency, sociocultural adaptation difficulty, and teaching self-efficacy and found that even though there were positive relationships between ITAs' perceived English proficiency and their teaching self-efficacy, as sociocultural adaptation difficulty decreased, the effect of perceived fluency in English on their teaching self-efficacy also decreased. Because teaching self-efficacy is an important component of both socialization and effective instruction, understanding how we can improve this metric could significantly impact ITAs experiences and effectiveness. The following section introduces a model that addresses this focus.

\section{Conceptual Framework}

Even though topics such as students' socialization, sense of belonging, and teaching self-efficacy have received significant attention in research, less work has focused specifically on these topics related to ITAs. This study is able to contribute to existing scholarship by offering a more nuanced understanding of the complex experiences of ITAs, in particular, by identifying important components for building a CoP designed for ITAs. Models that provide opportunities for socialization, sense of belonging, and teaching self-efficacy are in their infancy (Jia \& Aldous Bergerson, 2008), and developing effective ways to provide these opportunities for ITAs may address this gap.

Ongoing professional development models can impart knowledge and information while simultaneously creating a sense of community (Cox \& McDonald, 2017; Wenger, 1998). CoPs have been broadly adopted as effective frameworks for change and innovation in higher education, working primarily with faculty and institutional change efforts (Cox \& McDonald, 2017; Thompson, 2015; Vescio, Ross, \& Adams, 2008). More recently, universities are adopting the tenets of learning communities or CoPs as a way to onboard new faculty and graduate teaching assistants (Richlin \& Essington, 2004), and several models exist specifically addressing the orientation of ITAs (Ashavskaya, 2015, 2018; Jia \& Aldous Bergerson, 2008; Swan et al., 2017). Effective and innovative approaches to ITA development have the potential to improve ITAs' teaching efficacy and also assist with positive socialization into their graduate career.

Accordingly, the researchers of this study developed a pilot program to socialize ITAs through a CoP structured to create sense of belonging, enhance academic success, and improve teaching selfefficacy. The CoP was organized to provide repeated opportunities for ITAs to engage with each other

Journal of the Scholarship of Teaching and Learning, Vol. 20, No. 3, December 2020. josotl.indiana.edu 
and acquire much-needed information as they collaboratively experienced their first semester teaching at a public land-grant university. This study was designed to examine the influences of this specialized support for the ITA participants.

\section{Description of the Community of Practice}

According to Lave and Wenger (1991), CoPs tend to consist of three major components. First, a common area of interest needs to exist. Second, an established and bounded community needs to be present. Third, the group needs to develop and sustain established practices. In the context of the ITA CoP in this study, the shared domain included an interest in addressing common challenges as ITAs and in increasing teaching self-efficacy within a university-supported community group. The practices consisted of formal and informal discussions, the development and sharing of resources and information, as well as problem-solving amongst group members (Lave \& Wenger, 1991).

Guidelines for community-based professional development dictate that the optimal number of participants ranges from six to twelve individuals (Cox \& McDonald, 2017). The researchers initially recruited seven participants, five of which met regularly (four times during fall 2018); each meeting lasted 90 minutes. During each meeting session, participants had time to discuss the challenges and opportunities they encountered while engaging in graduate school as ITAs, for which, they provided peer support by offering feedback to each other. In addition, two CoP facilitators, one of whom is a veteran ITA, and the other an American graduate student, provided training specifically designed to enhance teaching self-efficacy and sense of belonging. The trainings focused on skills for public speaking and cross-cultural teaching as well as effective use of campus resources for teaching and learning.

\section{Researcher Positionality}

Throughout the study, the researchers discussed the fact that one of the research team members, who also served as a CoP facilitator, had worked as an ITA at some point in his graduate studies. This member identified as a speaker of English as a foreign language, while the other two members identified as native speakers of English. Racially, one member identified as non-White. Two of the members identified as women and one as a man. In qualitative inquiry, bracketing is an important concept, which consists of recognizing and discussing how the different positionalities, perceptions, and values of each researcher may influence engagement with participants and interpretations of data (Gearing, 2004). The researchers were aware of their identity differences in gender, language, nationality, and race among themselves and took these differences into account while engaging in the process of analyzing the data and interpreting the results. The discussions focused on these topics served to mitigate bias and acquire a clearer understanding of the phenomenon (Gearing, 2004).

\section{Methods}

Upon approval from the Institutional Review Board, the researchers used a multi-method case study approach to explore ITAs' involvment in a teaching-focused CoP during the first semester of their graduate studies. Case study methodology was appropriate because it allowed for the in-depth and holistic analysis of participants' experiences in the CoP over an extended time period within the university setting (Merriam, 2007). The institutional context was important as its international undergrad and graduate student population consisted of $9 \%$ during the time of the study, but did not

Journal of the Scholarship of Teaching and Learning, Vol. 20, No. 3, December 2020. josotl.indiana.edu 
offer any formal or required orientation for international teaching assistants. The study was guided by the following research questions:

1. How do ITAs experience participation in a community of practice in a public university in the Northeastern United States?

2. In what ways does participation in a community of practice affect ITAs' socialization, sense of belonging, and teaching self-efficacy in the university?

\section{Data Collection}

According to Johnson, Onwuegbuzie, and Turner (2007) a multi-methods design is appropriate when investigators are interested in understanding their phenomena through various perspectives. Because the researchers were interested in the experiences of ITAs participating in a CoP, as well as how participation in the CoP was related to their teaching self-efficacy and sense of belonging in a university setting, data collection involved three electronic post-questionnaires, three journal entries, and two group interviews. An electronic post-questionnaire was implemented to all participants via Qualtrics after the first three sessions. The questionnaires consisted of several close-ended questions measuring the effectiveness of the content of each CoP session. It also included one to two openended questions related to how the ITAs might apply what they had learned in the CoP to their teaching practice. The second component of the study included an electronic journal that was delivered after the first three sessions via Qualtrics. In the journal, participants responded to prompts developed by the research team to help them reflect on their experiences both in and out of the CoP that were related to teaching and socialization.

After the last CoP meeting, participants were invited to participate in one of two in-person group interviews, which lasted between 60-90 minutes. The first group consisted of five men, and the second had one woman and one man. In both group interviews, participants reflected on their experiences in the CoP throughout the semester. Group interviews were conducted primarily to garner information regarding participants' aggregate experiences in the CoP from a collective sense-making perspective. The interviews were audio-recorded, transcribed, and analyzed by members of the research team.

\section{Data Analysis}

Utilizing a thematic analytical approach, data analysis for this study was separated into three categories (questionnaires, group interviews, and electronic journals). This method was appropriate as we were seeking to locate, examine, and explain the themes that emerged within our data set (Braun \& Clarke, 2006). In our analysis, we followed Braun and Clarke's description of themes, which embodied "something important about the data in relation to the research question, and represents some level of patterned response or meaning within the data set" (p. 11).

Independently, each member of the research team selected and analyzed one facet of the data. For the open-ended questions in the questionnaires and data collected from the electronic journals, the researchers allowed codes and themes to emerge through a process of inductive and open coding. The journal prompts invited the participants to document their daily academic, social, and teaching challenges and engage in ongoing reflection on how these experiences were connected to what they experienced and learned in the CoP. Four out of six participants kept the journal throughout the semester-long initiative. In total, seven journal entries from the four participants including 21 responses to the three overarching questions were analyzed. The group interviews were the largest data source and consisted of a process of both inductive and deductive coding. First, the researcher

Journal of the Scholarship of Teaching and Learning, Vol. 20, No. 3, December 2020. josotl.indiana.edu 
explored the data allowing themes and patterns to emerge from participants' voices. Second, the researcher examined the data against themes aligned with the literature focused on the tenets of CoP and developing a sense of belonging. This process was conducted twice to ensure accurate coding and interpretation (Merriam, 2007) before sharing the analysis with the team.

Together, the researchers analyzed all forms of data through axial coding and selective coding (Merriam, 2007). This process allowed the researchers to explore convergences and divergences and identify core themes that emerged from each of the data sources (Merriam, 2007). By first analyzing the data separately and then as a team, the researchers established confirmability and credibililty of the findings and obtained clarity of categories by engaging in a circular coding process of peer review (Guba \& Lincoln, 1994).

\section{Participant Recruitment}

Participant requirement was based on the following criteria. First, participants had to be non-native speakers of English. Second, they had to be foreign-born. Finally, they had to be at least 18 years of age and be hired as graduate teaching assistants at the university. Researchers invited potential participants through emails sent by researchers and through online advertisements by the Center for Innovation in Teaching and Learning and the university's graduate school. Five individuals that were recruited regularly participated. Table 1 provides a summary of information on self-reported participant demographics, how proficient they perceived their English to be, and how confident they felt in terms of teaching in English.

Table 1. Participant demographics and self-reported language and teaching proficiency

\begin{tabular}{|c|c|c|c|c|c|c|}
\hline$\underline{\text { Gender }}$ & Nationality & $\frac{\text { Degree }}{\underline{\text { Sought }}}$ & $\begin{array}{l}\text { First } \\
\text { Language }\end{array}$ & $\begin{array}{l}\text { English } \\
\text { Proficiency* }\end{array}$ & $\frac{\text { Confidence }}{\underline{\text { Level }^{* *}}}$ & $\begin{array}{l}\frac{\text { Experience }}{\text { Teaching in }} \\
\underline{\text { U.S. }}\end{array}$ \\
\hline Male & Iraq & Ph.D. & Arabic & Advanced & Confident & Yes \\
\hline Male & NA & Ph.D. & NA & Intermediate & $\begin{array}{l}\text { Somewhat } \\
\text { confident }\end{array}$ & No \\
\hline Male & Iraq & Ph.D. & Arabic & Intermediate & $\begin{array}{l}\text { Somewhat } \\
\text { confident }\end{array}$ & No \\
\hline Male & Colombia & Master's & Spanish & Basic & $\begin{array}{l}\text { Not at all } \\
\text { confident }\end{array}$ & No \\
\hline Male & Ghana & Master's & $\mathrm{Ga}^{* * *}$ & Advanced & Confident & Yes \\
\hline Female & Taiwan & $\begin{array}{l}\text { Non-Degree } \\
\text { Student }\end{array}$ & Mandarin & Advanced & $\begin{array}{l}\text { Somewhat } \\
\text { confident }\end{array}$ & No \\
\hline
\end{tabular}

Notes. NA - no answer provided.

*In response to the question: "Overall, how would you rate your English proficiency?"

** In response to the question: "How confident, if at all, are you in teaching in English?"

*** English is an official language in Ghana; participant speaks Ga as first language. 


\section{Findings and Discussion}

This study was guided by two foci. First, the researchers were interested in how participants experienced the three core elements of the ITA CoP: navigating campus resources, public speaking, and cross-cultural teaching. Second, the researchers aimed to understand how the CoP assisted participants with socialization, sense of belonging, and teaching self-efficacy. Accordingly, the findings are presented in the context of the aforementioned three major CoP tenets, i.e., common interest, presence of community, and established practices. Interwoven in this discussion is an examination of how the CoP influenced socialization, sense of belonging and teaching self-efficacy. The findings that emerged from the analysis of the two group interviews are supplemented with findings from the questionnaires and electronic journals and presented in the sub-sections below.

\section{Common Interests}

The CoP was designed with teaching self-efficacy as the primary shared interest for participants. However, participants expressed that language was an equally important common interest in the group experience. As the interview and journal excerpts in this subsection illustrate, because of their shared identity as foreign-born language-minority TAs, some of the experiences and challenges they encountered were rather similar.

\section{Teaching Self-Efficacy}

Specifically, in the group interviews, participants noted the importance of their common interest in enhancing their teaching self-efficacy as both a bond and conduit that aided them in learning from each other, building self-confidence, and increasing feelings of belonging at the university.

For example, one ITA expressed, "I noticed that, yes, we are in the same situation, and I learn from other people's experiences and ability to deal with situation[s] that they are facing, even if I'm not facing." Another referred to developing confidence through their shared experience, asserting, "I did have confidence more. It is also this that there are some challenges I am also facing is same as what everyone else also is facing, or like, yeah, this is not just an unusual challenge to me but is for everyone, so I was more confident." In one group interview, a participant noted how the common interest helped with their feelings of belonging, stating, "I felt a sense of belonging because it brought different people for me of diverse background[s] who are also internationals all together in a way sharing ideas and any kind of problem we meet outside." These quotes served as a representation of participants' reflections about the first tenet of the CoP during the group interviews. They also support existing literature citing the importance of finding community in enhancing sense of belonging for international students (Chavajay, 2013).

\section{Language}

In addition, common experiences surrounding language were also recorded in participants' electronic journals. While many participants considered their faculty teaching supervisors to be very supportive, several of them cited language and communication as a prominent barrier. For instance, one participant wrote in his journal, "My supervisor is very supportive. The only challenge that I have is the language. Though I understand people easily and knowing almost all words I want to say, the accent makes me less confident." To this participant, comprehending the English language, both in the spoken form and in terms of vocabulary, is not as much a challenge as how his foreign accent makes him feel insecure. According to Yao (2016a), for international students, language is closely

Journal of the Scholarship of Teaching and Learning, Vol. 20, No. 3, December 2020. josotl.indiana.edu 
related to their identities and sense of belonging in the university community. This is even more true for ITAs, compared to other international students, because they have to use English within an additional dimension of their campus life, i.e., teaching; therefore, it is not difficult to understand why ITAs are concerned about their English ability.

The participant's comment on insecurity about his accent also highlights the power structure embedded in language use. Accents have important implications in cross-cultural interactions, especially when the interactions are examined through the concept of accepting or rejecting communicative burden (Lippi-Green, 2012). According to Lippi-Green, when a person refuses to communicate, he or she can respond, "I don't understand you," even though he or she can perfectly understand what is being communicated. This is done to put the communicative burden on the other person. When this interaction takes place in the context of U.S. English, Lippi-Green argues that native speakers can decide whether or not to participate in the communication when they are confronted with an accent that is foreign to them. In other words, members of the dominant language group have the power to reject their communicative responsibility and demand the person with an accent to carry most of the communicative burden. As part of the language minority, ITAs' confidence in communicating with their students, peers and supervisors may be dependent on how they feel they can tackle the communicative burden placed upon them.

Language also had an important role in the structure of the CoP in terms of the language fluency of the facilitator. The facilitator role is important in ongoing professional development models such as these (Ortquist-Ahrens \& Torosyan, 2009). One of the lead facilitators for the ITA CoP described in this study is a non-native English speaker and an ITA on campus. When asked about the role of the facilitator during the group interviews, several participants noted how this was an key feature in their feeling comfortable in the CoP. Though they recognized that a native English speaker had certain strengths, these were not as important as sharing the experience of language as a barrier with the facilitator. For example, when describing the facilitators one participant stated:

The non-native English speakers are the best because we are in the same shoes as they've already been in our shoes before. Yeah, so they are the best. But in general, we need, let me see, a native English speaker to just kind of compliment they can adapt to make it more better, yeah.

Participants also suggested a native English speaker as one who could help decode the higher education experience for them, asserting:

... the facilitator could then explain why students have this kind of feeling or what their adjectives actually mean (laughter). So I think it is just adding someone, just adding a native speaker as a teacher would be a good idea.

These comments from participants demonstrated that when designing CoPs for ITAs, language use and facilitators' linguistic and teaching backgrounds should be taken into account in order to increase the effectiveness of these types of CoPs. This finding is supported in literature that discusses the importance of language skills and cultural sensitivity when considering ITA specific training programs (Jia \& Aldous Bergerson, 2008)

\section{Presence of Community}

Aligned with CoP tenets (Lave \& Wenger, 1991), the CoP was designed as a semi-structured, supportive, and consistent group with self-selected membership that met throughout the participants'

Journal of the Scholarship of Teaching and Learning, Vol. 20, No. 3, December 2020. josotl.indiana.edu 
first semester teaching on campus. Building on participants' shared interest, the ITAs were encouraged to engage in learning, sharing, and supporting each other, which contributed to the development of group membership, group identity, co-learning, and socialization.

\section{Group Membership}

When participants were asked about the experience of belonging to this group, one participant said, "Yeah, because this kind of brings us together as international TAs, so in case we meet outside on campus, we can still have some interactions, you know, so that would impact my fellow international TAs." A second participant mentioned their experience learning from each other, reporting:

Teaching in the U.S. is kind of different from everyone's home country. So, with the new differences we are facing, how are we able to confront those challenges? Ok, yeah, so it was more about getting ideas from other ITAs and they were also able to share their experiences.

This quote highlighted participants' experiences in sharing and learning from each other with regard to enhancing their academic effectiveness and teaching self-efficacy.

Some participants also recorded in their journal how they interacted with other participants outside of the meeting time, as one participant wrote, "I discussed with my friend who attend this workshop some ideas of teaching."

In questionnaire responses, when asked about the value of the the initial CoP meeting that discussed teaching resources, many responses aligned with feeling more a part of the community at large, understanding where to find people with shared goals, "The most valuable is that I found people that are really interested in learning how to teach well. That makes the process really worthy for me because being a professor is something that I really desire to be"; where to find resources on campus, "I know if my students and I need help, whom and where I could turn to"; or how to navigate specific challenges they are likely to encounter, "I know what to do in several situations for example, if I had a student with mental problems or If I wanted to improve an answer for a student." Given that these ITAs had all experienced orientation events and in some instances departmental trainings where some of this information was likely covered, it appears how it was provided through the CoP had a stronger impact.

Participants' comments clearly highlighted the importance and impact of group membership within the collective group identity of the ITA CoP. These findings are reflected in the literature as well. Hodgkinson-Williams, Slay, and Sieborger (2008) found that the learning process could be strengthened as a result of the co-learning and group identity that occurred in the CoP model.

\section{Socialization}

An additional theme that emerged within the second tenet of CoPs was related to socialization. That is, participants learned commonly accepted practices, behavior, language, and actions from each other and the two facilitators. This process was successful for several reasons. First, participants experienced the shared commonality as ITAs, which created a connection and served as an entry to trust and community building. Second, participants began to feel comfortable and rely on each other due to their shared challenges as ITAs and because of the stability of the CoP structure.

As a result, participants expressed elements of socialization that helped them socially, professionally, academically, to integrate into the university setting. Describing the social setting, one participant said, "I enjoy atmosphere, the way that it was open; it was like, similar to the concept that we have here [in the focus group]. It was more open, we could interrupt each other." Speaking to the

Journal of the Scholarship of Teaching and Learning, Vol. 20, No. 3, December 2020. josotl.indiana.edu 
learning of appropriate behaviors in a professional setting, one participant asserted, "It is how we exchange our ideas and listen to other people's experiences. I think it will, somehow, it will make me feel that, okay, whether I'm doing is right, or do I have some room to improve." Similarly, when asked what was most valuable following the second CoP session about teaching self-efficacy, participants listed "discussion and openness," "sharing other experiences in teaching," and "exchanging ideas and thoughts." With regard to helping them academically, several participants mentioned that the public speaking session helped them not only in their teaching, but also in presentations in their graduate studies.

The literature notes that CoPs have been successful in faculty professional development for very similar reasons - the respected and open exchange of ideas an a normalization process (e.g., Hoadley, 2012; Hodgkinson-Williams et al., 2008; Thompson, 2015). For ITAs, the community validated that many of their shared experiences were not merely a result of being international students, but garnered from their common status as instructors. For example, when asked what was most valuable about cross-cultural teaching, one participant replied "knowing that we have similar situations" referring to both domestic and international teaching assistants experiences. Ultimately, this built-in and semi-structured community helped participants with socialization into graduate school as students and as instructors.

\section{Established Practices}

Lave and Wenger (1991) maintain that established practices are the third major component of the CoP model. According to Hoadley (2012), practices in CoPs include "the process of knowledge generation, application, and reproduction" (p. 20). Hence, co-facilitators of the group invited guest speakers who focused on public speaking, cross-cultural interactions, and teaching resources on campus. Each session consisted of the sharing of information, knowledge, and experiences, how they could be applied, and how they could be translated and reproduced in participants' lives. Participant quotes supporting this theme centered on gaining resources from the sessions and applying them to their personal, professional, or academic experiences, which resulted in vicarious learning and increasing self-confidence.

\section{Vicarious Learning}

Vicarious learning occurs when one individual learns through listening to others' experiences rather than directly experiencing the situation (DeChenne et al., 2012). This concept emerged as a major theme when considering the benefits of the CoP. For example, one participant noted, "The first session taught me that [students] really should come to class. I should really include some rules and regulations that is best and also in relation to the department's rules and regulations." Another participant reflected on the benefits of learning from a guest speaker, who was also a seasoned ITA, about how to addresses challenges as an ITA in the U.S., stating:

Teaching in the U.S. is kind of different from everyone's home country. So, with the new differences we are facing, how are we able to confront those challenges. Okay, yeah, so it was more about getting ideas from other ITA's and they were also able to share their experiences and if they had a particular problem, this is what they do.

In both group interviews, participants consistently discussed vicarious learning by gaining strategies and skills from the speakers and other participants that could be directly applied to their own teaching practices and experiences in graduate school. For instance, one participant reflected on

Journal of the Scholarship of Teaching and Learning, Vol. 20, No. 3, December 2020. josotl.indiana.edu 
the benefit of learning from other participants in the group, stating, "I noticed that, yes, we are in the same situation, and I learn from other people's experience and ability to deal with situation that they are facing, even if I'm not facing, but it's a good way to know something how you can track if something happened, or you can use that methodology to have a better interaction." Another participant in a questionnaire response asserted, "The most valuable part of the session was to know my colleagues' experiences, and to [learn about] some cases that seem really difficult to approach."

The value and cultivation of confidence was a significant recurring theme that resulted from vicarious learning, appearing in the group interviews, journals, and questionnaires. In questionnaire responses, when asked how they would use what they learned as a graduate student after the second session, all of the respondents mentioned confidence in some context; for example, "it gives more confidence for future interactions", “...the more you confident, the better your speaking.” In journal responses, more context was provided. For example, one participant wrote:

I felt more confident lately. That confidence came from a good understanding of my topic. The last lab I spent four hours performing the lab. The following days, the students came up with questions and I answered them correctly and very quickly.

This participant received the advice from the other participants to be better prepared for a class by reviewing the course materials to the best extent he could as a way to increase confidence while teaching. He prepared accordingly by familiarizing himself with the subject matter of his teaching, and he was able to answer students' questions with speed and accuracy, which resulted in his enhanced confidence.

During the group interviews, the majority of participants expressed feeling a sense of increased self-confidence simply by listening to others' experiences. For example, a group interview participant reflected on finding confidence in knowing everyone struggled with the language barrier, stating, 'Even if you don't know, like, you feel less confident, but when we learn, ok, I mean, my big, biggest challenge was the language, but everybody else same problem, so it's not just me. So, I can work on it, but maybe should not stop me to keep doing what I do." Experiences such as this one were common in the CoP and fell within the concept of vicarious learning. This finding was reflected in the literature and connected directly to teaching self-efficacy. In their study focused on improving teaching self-efficacy of graduate teaching assistants, DeChenne et al. (2012) found that vicarious learning through instructor and peer interactions was an important factor for increasing teaching selfefficacy. Similarly, participants in this study reported more confidence in teaching and provided examples of how their teaching had improved as a result of vicarious learning during the CoP. While self reported, instructor and peer engagement and feedback were found to be crucial elements to improving ITA teaching practices.

The findings indicated that the learning community served as an intervention of support for ITAs. In particular, the group contributed to community building, co-learning, and strengthening skills and confidence based on that learning, which aligned well with the scope of the CoP model (Lave \& Wenger, 1991). Findings also suggested that participation enhanced teaching self-efficacy, heightened self-confidence, strengthened social relationships, assisted with socialization within the university setting, and increased their sense of belonging. Finally, it is important to note that engagement with the CoP potentially mitigated challenges researchers have noted ITAs typically encounter in graduate school such as isolation and depression (Shadowen et al., 2019), cultural dissonance (Singh, 2018), and academic difficulties (Curtis et al., 2013).

Journal of the Scholarship of Teaching and Learning, Vol. 20, No. 3, December 2020. josotl.indiana.edu 


\section{Limitations}

This study has several important limitations to discuss. Questionnaire responses were low and electronic journal entries were shorter than researchers had intended, which restricted opportunities for triangulation (Guba \& Lincoln, 1994). Additionally, while researchers used peer-review to corroborate the coding process, credibility of the findings was somewhat limited as well, as researchers were unable to conduct member-checking (Guba \& Lincoln, 1994). Finally, the use of qualitative inquiry reduced the likelihood of attaining full representation of the ITA population at the university (Shenton, 2004).

\section{Implications}

CoPs are designed to provide a safe, stable, and supportive environment for members to socialize, learn, share, and practice skills focused on a common topic of interest (Lave \& Wenger, 1991; Wenger, 1998). It is evident that the CoP provided a space for these actions and behaviors to occur. Based on the findings, the researchers concluded with the following implications for research and training practices.

None of the participants in this study is a speaker of English as a first language, and none identifies as racially White. Even though the relationship between English proficiency and teaching self-efficacy was explored in this study, participants' racial identity did not emerge as a theme. However, race and/or ethnicity often interacts with language in the context of education as illustrated in a study by Cho (2017) that explored the experiences of language-minority pre-service teachers through counter-narratives.

Race has significant implications for teacher authority in predominantly White institutions (PWIs) like the university featured in this study. According to Vargas (1999), in a primarily White campus, the classroom becomes a "contested terrain", and racial minority instructors often embody the image of an "other" when they do not resemble a "stereotypical academic authority figure" (p. 360). Several studies have featured narratives based on the experiences of racial and/or linguistic minority instructors in higher education (e.g., Rodriguez, 2008; Waring \& Bordoloi, 2013). These accounts, like those produced by the ITAs in this study, play a critical role in diversifying the understanding of instructors' identities and experiences in higher education.

In another study about factors that influence U.S. undergraduate students' judgments of nonnative English-speaking teaching assistants, Rubin (1992) found that the participants in his study stereotypically attributed differences in accent to the speech of an ethnically Asian instructor even though the instructor spoke standard English in real life. In addition, the participants' comprehension also seemed to be undermined simply by visually identifying the instructor as Asian. Therefore, future research on the impact of CoPs for ITAs could consider the intersection of race and language, especially in terms of how ITAs' racial identities mediate their confidence in teaching in English and their level of comprehensibility to their students.

Providing opportunities for ITAs to immediately socialize and connect with others through a CoP is a low overhead, high impact model for supporting this important population (Jia \& Aldous Bergerson, 2008). Though in this study the CoP was run through the Center for Innovation in Teaching and Learning, the requirements are such that these programs could easily be offered through International Programs Offices, individual departments that have a high number of ITAs, or in residence halls. Based on participant feedback, the frequency of meetings should not be less than once per month, though several participants felt that meeting more often would have built a stronger community. Of greatest importance, and addressed in our group interview, was providing both a nonnative English speaker, and a native English speaker as facilitators for the groups. This combination

Journal of the Scholarship of Teaching and Learning, Vol. 20, No. 3, December 2020. josotl.indiana.edu 
provided a strong sense of belonging through the connection of the shared experience with the nonnative English speaker and as fellow ITAs. In addition, when participants needed advice, they served as mentors and "authority" on language and U.S. cultural norms inside and outside the classroom.

Sense of belonging is a key component of positive socialization into higher education (Strayhorn, 2012). Based on this study, the CoP framework served as a promising approach to the development of sense of belonging by providing a space for community, friendship, socialization, and academic integration. While scholarship suggests that these concepts are particularly important for racial and ethnic minorities, such as international students (Museus et al., 2017), more research is needed to examine ways in which this distinct student population can be better supported by universities in their development as learners and instructors. Additional research could investigate the extent to which CoPs enhance international students' academic and social development, along with ways that CoPs could functionally be integrated into current ITA teacher training models.

While an introductory training workshop is typically offered at the beginning of the semester for ITAs, it is not a common practice for these individuals to meet throughout the semester (Jia \& Aldous Bergerson, 2008). Given the transition of ITAs from their home countries, and their potential loss of support systems (Chavajay, 2013), it would be beneficial for universities to offer a dedicated space for consistent interaction and support for these students. Because the CoP in this study provided a consistent community where individuals felt safe and supported by their peers, learned from each other, and strengthened their teaching self-efficacy, ITA specific CoPs could be an effectivre strategy to address the needs of ITAs on other college campuses moving forward.

\section{Acknowledgments}

We are grateful for the support of the Center for Innovation in Teaching and Learning at our research site. We would also like to thank Andrea Mercado, who served as our second Community of Practice facilitator.

\section{References}

Ashavskaya, E. (2015). International teaching assistants' experiences in the U.S. classrooms: Implications for practice. Journal of the Scholarship of Teaching and Learning, 15(2) 56-69. 10.14434/josotl.v15i2.12947

Ashavskaya, E. (2018). Mentoring international teaching assistants: A case study of improving teaching practices. InSight: A Journal of Scholarly Teaching. 13, 101-117.

Bair, R., \& Haworth, J. C. (2006). Doctoral student attrition and persistence: A meta-synthesis of research. (481-534). In J. C. Smart (Ed.), Higher Education: Handbook of Theory and Research. Kluwer Academic Publishers.

Braun, V., \& Clarke, V. (2006) Using thematic analysis in psychology, Qualitative Research in Psychology, 3(2), 77-101. 10.1191/1478088706qp063oa

Chalupa, C., \& Lair, A. (2000). Meeting the needs of international TAs in the foreign language classroom: A model for extended training. U.S. Department of Education. (ERIC Document Reproduction Service No. ED481005).

Chavajay, P. (2013). Perceived social support among international students at a U.S. university. Psychological Reports, 112(2), 667-677. https://doi.org/10.2466/17.21.PR0.112.2.667-677

Cho, H. (2017). Racism and linguicism: Engaging language minority pre-service teachers in counter storytelling. Race, Ethnicity and Education, 20(5), 666-680. https://doi.org/10.1080/13613324.2016.1150827

Journal of the Scholarship of Teaching and Learning, Vol. 20, No. 3, December 2020. josotl.indiana.edu 
Cox, M. D., \& McDonald, J. (2017). Faculty learning communities and communities of practice: Dreamers, schemers, and seamers. In J. McDonald \& A. Cater-Steel (Eds.), Communities of Practice (pp. 47-72). Springer.

Curtis, N., Stewart, A. J., \& Ostrove, J. M. (2013). Fostering academic self-concept: Advisor support and sense of belonging among international and domestic graduate students. American Educational Research Journal, 50(1), 108-137.

DeChenne, S. E., Enochs, L. G., \& Needham, M. (2012). Science, technology, engineering, and mathematics graduate teaching assistants teaching self-efficacy. Journal of the Scholarship of Teaching and Learning, 12(4), 102-123.

Gearing, R. (2004). Bracketing in research: A typology. Qualitative Health Research, 14(10), 1429-1452. https://doi.org/10.1177/1049732304270394

Glass, C. R. (2018). International students' sense of belonging-locality, relationships, and power. Peer Review, 20(1), 27-30.

Glass, C. R., Kociolek, E., Wongtrirat, E, Lynch, R. J, \& Cong, S. (2015). Uneven experiences: The impact of student-faculty interactions on international students' sense of belonging. Journal of International Students, 5(4), 353-367. https://www.ojed.org/index.php/jis/article/view/400

Glass, C. R., \& Westmont, C.M. (2014). Comparative effects of belongingness on the academic success and cross-cultural interactions of domestic and international students. International Journal of Intercultural Relations, 38, 106-19. http://dx.doi.org/10.1016/j.ijintrel.2013.04.004

Guba, E. G., \& Lincoln, Y. S. (1994). Competing paradigms in qualitative research. In N. K. Denzin \& Y. S. Lincoln (Eds.), Handbook of qualitative research (pp. 105-117). SAGE.

Hoadley, C. (2012). What is a community of practice and how can we support it? In D. H. Jonassen \& S. M. Land (Eds.), Theoretical foundations of learning environments (2nd ed., pp. 287-300). Routledge.

Hodgkinson-Williams, C., Slay, H., \& Sieborger, I. (2008). Developing communities of practice within and outside higher education institutions. British Journal of Educational Technology, 39(3), 433-442. https://doi.org/10.1111/j.1467-8535.2008.00841.x

Jia, C., \& Aldous Bergerson, A. (2008). Understanding the international teaching assistant training program: A case study at a Northwestern research university. International Education, 37(8), 77-98. https://trace.tennessee.edu/internationaleducation/vol37/iss2/8

Johnson, R. B., Onwuegbuzie, A., \& Turner, L. (2007). Toward a definition of mixed methods research. Journal of Mixed Methods, 1(2), 112-133. 10.1177/1558689806298224

Jung, E., Hecht, M. L., \& Wadsworth, B. C. (2007). The role of identity in international students' psychological well-being in the United States: A model of depression level, identity gaps, discrimination, and acculturation. International Journal of Intercultural Relations, 31(5), 605-624. 10.1016/j.ijintrel.2007.04.001

Kim, E. (2009). Beyond language barriers: Teaching self-efficacy among East Asian international teaching assistants. International Journal of Teaching and Learning in Higher Education, 21(2), 171180. http://www.isetl.org/ijtlhe/

Khawaja, N. G., \& Stallman, H. M. (2011). Understanding the coping strategies of international students: A qualitative approach. Australian Journal of Guidance and Counselling, 21(02), 203224. eprints.qut.edu.au

Lave, J., \& Wenger, E. (1991). Situated learning: Legitimate peripheral participation. Cambridge University Press.

Le, A. T, LaCost, B. Y., \& Wismer, M. (2016). International female graduate students' experience at a Midwestern university: Sense of belonging and identity development. Journal of International Students, 6(1), 128-152. https://www.ojed.org/index.php/jis/article/view/485

Journal of the Scholarship of Teaching and Learning, Vol. 20, No. 3, December 2020. josotl.indiana.edu 
Lippi-Green, R. L. (2012). English with an accent: Language, ideology, and discrimination in the United States. Routledge.

Lovitts, B. E. 2001. Leaving the ivory tower: The causes and consequences of departure from doctoral study. Rowman \& Littlefield.

Meadows, K. N., Olsen, K. C., Dimitrov, N., \& Dawson, D. L. (2015). Evaluating the differential impact of teaching assistant training programs on international graduate student teaching. Canadian Journal of Higher Education, 45(3), 34-55.

Merriam, S. B. (2007). Qualitative research and case study applications in education. (2 ed.). Jossey-Bass.

Museus, S. D., Yi, V., \& Saelua, N. (2017). The impact of culturally engaging campus environments on sense of belonging. The Review of Higher Education, 40(2), 187- 215. https://doi.org/10.1353/rhe.2017.0001

Mwangi, C. A. G. (2016). Exploring sense of belong among Black international students at an HBCU. Journal of International Students, 6(4), 1015-1037. https://www.ojed.org/index.php/jis/article/view/332

Okahana, H., \& Zhou, E. (2019). International graduate applications and enrollment: Fall 2018. Washington, DC: Council of Graduate Schools.

O’Neal, C., Wright, M., Cook, C., Perorazio, T., \& Purkiss, J. (2007). The impact of teaching assistants on student retention in the sciences: Lessons for TA training. Journal of College Science Teaching, 36(5), 24-29.

Ortquist-Ahrens, L., \& Torosyan, R. (2009). The role of the facilitator in faculty learning communities: Paving the way for growth, productivity, and collegiality. Learning Communities Journal, 1(1), 29-62.

Richlin, L., \& Essington, A. (2004). Faculty learning communities for preparing future faculty. New Directions for Teaching and Learning. 97, 149-157. https://doi.org/10.1002/tl.141

Rodriguez, D. (2009). The usual suspect: Negotiating White student resistance and teacher authority in a predominantly White classroom. Cultural Studies $\leftrightarrow$ Critical Methodologies, 9(4), 483-508. https://doi.org/10.1177\%2F1532708608321504

Rubin, D. L. (1992). Nonlanguage factors affecting undergraduates' judgments of nonnative English-speaking teaching assistants. Research in Higher Education, 33(4), 511-531. https://doi.org/10.1007/BF00973770

Shadowen, N., Williamson, A., Guerra, N., Ammigan, R., \& Drexler, M. (2019). Prevalence and correlates of depressive symptoms among international students: Implications for university support offices. Journal of International Students, 9(1), 129-149. https://doi.org/10.32674/jis.v9i1.277

Shenton, A. (2004). Strategies for ensuring trustworthiness in qualitative research projects. Education for Information, 22, 63-75. 10.3233/EFI-2004-22201

Singh, A. (2018). Investigating the sense of belonging of international students through a predictive model. (Doctoral dissertation). Graduate Theses and Dissertations database. (16467).

Strayhorn, T. (2012). College students' sense of belonging: A key to educational success for all students. Routledge.

Sun, J., Hagedorn, L. S., \& Zhang, Y. (2016). Homesickness at college: Its impact on academic performance and retention. Journal of College Student Development, 57(8), 943-957. https://doi.org/10.1353/csd.2016.0092

Swan, K.M., Kramer, S., Gopan, A., Shi, K., \& Roth, S.M. (2017). Beyond proficiency: An asset based approach to international teaching assistant training. The Journal of Faculty Development. 31(2), 21-27.

Thompson, K. V., Marbach-Ad, G., Egan, L., \& Smith, A. C. (2015). Faculty learning communities: A professional development model that fosters individual, departmental and institutional 
impact. In G. C. Weaver, W. D. Burgess, A. L. Childress, \& L. Slakey (Eds.), Transforming institutions: Undergraduate STEM education for the 21st century (pp. 312-324). Purdue University Press.

UNESCO. (2019). International or (internationally mobile) students. http://uis.unesco.org/en/glossary-term/international-or-internationally-mobile-students Vargas, L. (1999). When the "other" is the teacher: Implications of teacher diversity in higher education. The Urban Review, 31(4), 359-383. https://doi.org/10.1023/A:1023290300660

Vescio, V., Ross, D., \& Adams, A. (2008). A review of research on the impact of professional learning communities on teaching practice and student learning. Teaching and Teacher Education, 24(1), 80-91. http://dx.doi.org/10.1016/j.tate.2007.01.004

Waring, C. D. L., \& Bordoloi, S. D. (2013). "Hopping on the tips of a trident": Two graduate students of color reflect on teaching critical content at predominantly White institutions. Feminist Teacher, 22(2), 108-124.

Wenger, E. (1998). Communities of practice: learning, meaning, and identity. University Press.

Yao, C. W. (2016a). "Better English is the better mind": Influence of language skills on sense of belonging in Chinese international students. The Journal of College and University Student Housing, 43(1), 74-89.

Yao, C. W. (2016b). Unfulfilled expectations: Influence of Chinese international students' roommate relationships on sense of belonging. Journal of International Students, 6(3), 762-778. https://www.ojed.org/index.php/jis/article/view/355

Yeh, C. J., \& Inose, M. (2003). International students' reported English fluency, social support satisfaction, and social connectedness as predictors of acculturative stress. Counselling Psychology Quarterly, 16(1), 15. https://psycnet.apa.org/doi/10.1080/0951507031000114058

Yi, V., \& Saelua, N. (2018). How culturally engaging campus environments influence sense of belonging in college: An examination of differences between White students and students of color. Journal of Diversity in Higher Education, 11(4), 467-483. https://psycnet.apa.org/doi/10.1037/dhe0000069 